Огляди літератури, оригінальні дослідження, погляд на проблему, випадок з практики, короткі повідомлення УДК 577.122.82:616-00

DOI 10.11603/1811-2471.2021.v.i3.12504

\title{
ПОРУШЕННЯ СИНТЕЗУ І ФУНКЦІї СИРОВАТКОВОГО АЛЬБУМІНУ ПРИ РІЗНИХ ПАТОЛОГІЧНИХ СТАНАХ ОРГАНІЗМУ
}

\author{
๑Ю. Р. Дзьордзьо, С. М. Андрейчин, У. О. Мудра
}

Тернопільський національний медичний університет імені І. Я. Горбачевського МОз України

PЕзЮМЕ. В огляді висвітлені дані сучасної літератури про патологічні зміни метаболізму та функції сироваткового альбуміну при різних захворюваннях і патологічних станах.

Мета - провести аналіз публікацій про порушення функції сироваткового альбуміну та їх вплив на організм, а також показати перспективу подальших досліджень у даній сфері.

Матеріал і методи. У дослідженні використано бібліосистематичний та аналітичний методи. Проведено огляд та аналіз сучасної літератури в базах Medline та PubMed.

Результати. Коротко висвітлено сучасні уявлення про синтез і функції людського сироваткового альбуміну, причини збільшення та зменшення його концентрації в плазмі крові, кількісні й якісні зміни при різних патологічних станах. Висвітлено останні дані літератури про транспортні та антиоксидантні властивості альбуміну, його структурні зміни.

Висновки. Поширеність альбуміну в людському організмі і різноманіття його функцій обумовлює важливість впливу різних патологічних процесів на його метаболізм. Основними факторами, що викликають зміни в метаболізмі альбуміну, є захворювання, що призводять до порушення його утворення, збільшення втрати, перерозподіл між тканинами, а також структурні зміни, що впливають на функції цього білка.

КлючовІ СлОВА: альбумін; порушення синтезу і функції альбуміну; гіпоальбумінемія; гіперальбумінемія.

Вступ. Альбумін (від латинського слова albus білий) належить до найпоширеніших у тваринному і рослинному світі білків. Це простий глобулярний водорозчинний білок. Медичне поняття «альбумін» стосується лише до одного білка крові людський сироватковий альбумін (ЛСА). ЛСА - це неглікозильований білок із негативним зарядом. Має вигляд поліпептидного ланцюга із 585 амінокислот з молекулярною масою від 66,5 до 70 кДа, структурну послідовність яких вперше встановили J. K. Brown i B. Melonn [1].

ЛСА утворюється в основному в клітинах печінки. За добу полісомами, що зв'язані з ендоплазматичною сіткою гепатоцитів, синтезується близько 10-16 г альбуміну. В організмі немає запасу альбуміну, однак при потребі швидкість утворення його може бути збільшена до $300 \%$. Нормальна концентрація альбуміну плазми дорослої людини становить 35-50 г/л. У дітей до 3 років концентрація коливається від 25 до 55 г/л. У нормі ЛСА становить близько 55 \% від загального складу білків крові. Всього альбуміну в організмі близько 280 г, тобто приблизно 3 \% від загального білка в організмі. Синтез цього білка регулюється осмолярністю рідини інтерстицію печінки, осмотичним тиском колоїдних розчинів, рівнем кортикостероїдів, інсуліну та амінокислот $[2,3]$.

Завдяки особливостям структури сироватковий альбумін виконує багато функцій в організмі: регулює колоїдно-осмотичний тиск у плазмі крові та інших біологічних рідинах; виконує транспортну функцію, маючи здатність зв'язуватись 3 жирними кислотами, гормонами, оксидом азоту, іонами кальцію та хлору. Крім того, альбумін транспортує багато синтетичних лікарських засобів; виконує роль антиоксиданта; $є$ модулятором процесів запалення; виводить екзо- та ендотоксини; має вплив на систему коагуляційного гемостазу $[1,4]$.

Мета - провести аналіз публікацій про порушення функції сироваткового альбуміну та їх вплив на організм, а також показати перспективу подальших досліджень у цій сфері.

Матеріал і методи дослідження. У дослідженні використано бібліосистематичний та аналітичний методи. Проведено огляд та аналіз сучасної літератури в базах Medline та PubMed.

Результати й обговорення. Найчастішими причинами порушення функції сироваткового альбуміну $є$ збільшення або зменшення його концентрації в плазмі крові $[1,5,6]$.

Гіперальбумінемія найчастіше супроводжує гостре зневоднення організму, однак його перерозподіл між кровоносним руслом і тканинами, а також корекція синтезу відбуваються досить швидко, тому зміни онкотичного тиску компенсуються. Гіпоальбумінемія може бути спричинена зменшенням вироблення, збільшенням втрат, перерозподілом або розведенням альбуміну. У пацієнтів із середньою та тяжкою гіпоальбумінемією нерідко відбувається накопичення рідини, зменшення об'єму плазми та виникає тромбоемболія [7]. Гіпоальбумінемія $\epsilon$ поширеною знахідкою у пацієнтів із тяжкими захворюваннями. Помірна або тяжка гіпоальбумінемія (при зниженні рівня альбуміну <2 мг/дл) може негативно впли- 
Огляди літератури, оригінальні дослідження, погляд на проблему, випадок з практики, короткі повідомлення

нути на клінічний перебіг та на прогноз. Водночас, гіперальбумінемія клінічно спостерігається лише при гемоконцентрації, що не є клінічно значущою проблемою. У центрі уваги різноманітних дослідників, як правило, залишається причина та лікування гіпоальбумінемії [8].

На синтез альбуміну впливають багато факторів, але клінічне значення має зниження продукції, як правило, обумовлене печінковою недостатністю, запаленням або хронічним недоїданням. Оскільки печінка $є$ основним місцем утворення альбуміну, печінкова недостатність із зниженням понад 75 \% функції печінки може призвести до гіпоальбумінемії $[3,9,10]$.

Окрім недостатності синтезувальної здатності гепатоцитів, гіпоальбумінемії в осіб з порушеннями функції печінки можуть сприяти також інші механізми. У пацієнтів із запальними захворюваннями печінки продукція альбуміну може зменшитися через його функцію як негативного гострофазного білка. У хворих із цирозом, що супроводжується портальною гіпертензією, який спричиняє асцит, новосинтезований альбумін у значно меншому обсязі потрапляє в системний кровообіг, тому знижується його концентрація в сироватці крові. Натомість велика частина нещодавно синтезованого альбуміну потрапляє в асцитичну рідину поза внутрішньосудинним руслом. Білок залишає печінкову паренхіму і надходить в очеревинну рідину шляхом ексудації через капсулу печінки або через печінкову лімфатичну систему $[11,12]$.

Захворювання, що супроводжуються вираженим системним запаленням - часта причина гіпоальбумінемії. Під час запального процесу цитокіни, такі як фактор некрозу пухлин та інтерлейкін-1, стимулюють перерозподіл амінокислот від вироблення білків, не важливих для запального процесу, перенаправляючи їх до позитивних гострофазних білків, включаючи глобуліни, фібриноген і гаптоглобін. Водночас швидкість синтезу негативних білків гострої фази, таких як альбумін, падає. Зниження концентрації альбуміну в плазмі під час запалення може бути значним $[2,13]$.

Виражене зниження вмісту альбуміну в крові також $\epsilon$ клінічним наслідком захворювань, які спричиняють втрату білка. Значна кількість лСА може бути втрачена у зв'язку з кровотечами, а також нефропатією, ентеропатією чи дерматопатією. Гостра та хронічна крововтрати призводять до втрати всіх складників цільної крові, включаючи еритроцити, альбумін та глобулін. Нефропатії, що супроводжуються втратою білка (наприклад, гломерулонефрит або амілоїдоз нирок, а також цукровий діабет, гіпертонічна хвороба), є наслідком зміни клубочків нефронів з порушенням механізму фільтрації [14]. Незважаючи на те, що роз- мір молекули альбуміну приблизно однаковий $з$ розміром пор клубочка, втрата альбуміну в нормі через фільтрацію мінімальна (0,004 \%), оскільки на базальній мембрані клубочка є сильний негативний заряд. Негативно заряджені молекули альбуміну відштовхуються від базальної мембрани через однаковий заряд. Однак при нефропатіях негативний заряд, який зазвичай присутній на клубочках, втрачається, а пори клубочків розширюються. Оскільки інші неальбумінові білки мають більший розмір, вони утримуються пошкодженим клубочком, тому гіпоальбумінемія досить часто супроводжується нормальними або навіть дещо підвищеними концентраціями глобулінів в плазмі крові $[8,15]$.

Втрата альбуміну також може відбуватися зі схожими механізмами як при ентеропатіях, так і при дерматопатіях, що супроводжуються втратами білка загалом. Унаслідок цих патологічних процесів виникають великі ексудативні поверхні, незалежно від того, знаходяться вони в кишечнику (його тяжкі запальні захворювання) або на шкірі (значні термічні опіки, токсичний епідермальний некроліз) $[16,17]$.

Поряд з кількісними змінами на функцію альбуміну можуть впливати також його якісні зміни.

Молекула альбуміну проявляє антиоксидантну здатність. Ця корисна властивість залежить від будови молекули. У здорових людей пошкодження альбуміну та, відповідно, зниження його антиоксидантних властивостей, вважаються «біологічно незначними» через велику кількість цього білка в плазмі [5]. Крім того, відомо, що пошкоджені молекули альбуміну швидко виводяться з обігу та деградують. Однак останні дослідження показали, що більш виражені зміни антиоксидантних властивостей пошкодженого альбуміну можуть бути пов'язані з патологічними станами $[18,19]$.

Протягом свого життя (понад 20 днів) молекула альбуміну циркулює в крові близько 15 тис. разів. За цей період вона зазнає певних ушкоджень, що впливає на її антиоксидантні властивості. Ці зміни можуть мати місце при цукровому діабеті, який є одним із патологічних станів, що пов'язані з ранньою появою судинних ускладнень, поряд із функціональними змінами альбуміну $[19,20]$.

При цьому захворюванні альбумін зазнає підвищеного гліколізування. Це явище полягає у неферментативному приєднанні молекули глюкози до вільного залишку первинного аміну. Перегрупування Амадорі гліколізованого білка призводить до утворення шкідливих прогресивних кінцевих продуктів глікування. Існують докази, що антиоксидантна властивість альбуміну змінюється після гліколізування in vitro метилгліоксалем. 
Огляди літератури, оригінальні дослідження, погляд на проблему, випадок з практики, короткі повідомлення

Дослідження Favier et al. [21] показало, що погіршення антиоксидантних властивостей сироваткового альбуміну відбувається у хворих на цукровий діабет. Було показано, що активність зв'язування глікованого ЛСА з міддю нижча, ніж у неглікованого. Вміст альбуміну в залізозв'язувальній антиоксидантній системі помітно знижується при цукровому діабеті. Глікування альбуміну спричиняє зменшення антиоксидантної активності цієї молекули до індукованого міддю окислення холестеролу ліпопротеїнів низької щільності (ЛПНЩ) [22].

Крім того, глікований альбумін ще й посилює індуковане міддю окиснення лПнЩ, ймовірно, утворюючи супероксид. Альбумін також транспортує триптофан, найбільшу та найважливішу амінокислоту. Зв'язування триптофану зменшується в глікованому альбуміні. Існують докази, що глікований альбумін in vitro посилює окислювальну шкоду в адипоцитах.

Зв'язування кінцевих продуктів глікування 3 клітинними рецепторами кінцевих продуктів глікування ініціює внутрішньоклітинне утворення активних форм кисню, в основному накопичення карбоксиметил лізину, що супроводжується прооксидантним і прозапальними ефектами в тканинах. Окрім того, згідно з даними дослідження, глікований альбумін погіршує активність судинної ендотеліальної NO-синтази in vivo в аортах кролика. Також було показано, що модифікований гіпохлоритом альбумін зв'язується з рецепторами кінцевих продуктів глікування у стінці артерії та викликає експресію хемотаксичного білка-1 моноцитів, сприяючи запальним ускладненням в артеріальній стінці [16]. Глікований альбумін також чинить токсичну дію на мікрогліальні клітини, що пов'язано з порушеннями клітинних протеолітичних систем. Було описано участь кінцевих продуктів глікування у нейродегенерації. Оскільки альбумін через глікування зазнає структурних змін, очевидно, що поряд зі зниженням антиоксидантних властивостей він також зменшує здатність зв'язувати ліганди, однак такі зміни властивостей альбуміну при цукровому діабеті ще недостатньо вивчені [23].

Висновки. Проведений огляд літератури висвітлює важливі проблеми метаболізму альбуміну, а також патологічні зміни, що виникають у людському організмі внаслідок порушень його синтезу і функції. На сьогодні виконано багато досліджень, що вивчають це питання, вони показують тісний взаємозв'язок між порушеннями метаболізму альбуміну і різними патологічними станами організму. Найбільший вплив на порушення функції цього білка чинять патологічні стани, що супроводжуються його недостатнім синтезом і втратою з кровоносного русла та тканинних просторів. Однак функція альбуміну може значно порушуватися також при захворюваннях, що викликають його структурні зміни.

Перспективи подальших досліджень. Важливість альбуміну, як найпоширенішого в організмі білка, а також різноманіття його корисних функцій спонукає до подальших досліджень патологічних впливів різних захворювань на процеси його метаболізму. Розуміння аспектів взаємозв'язку між порушенням синтезу і функції альбуміну та різними патологічними процесами, а також механізмів цих порушень, дозволить запропонувати шляхи корекції метаболізму альбуміну і його функції, що матиме позитивний вплив на лікування багатьох захворювань.

\section{ЛІТЕРАТУРА}

1. Levitt D. G. Human serum albumin homeostasis: a new look at the roles of synthesis, catabolism, renal and gastrointestinal excretion, and the clinical value of serum albumin measurements / D. G. Levitt, M. D. Levitt // Int. J. Gen. Med. - 2016. - No. 9. - P. 229-255.

2. Sakata N. Contribution of superoxide to reduced antioxidant activity of glycoxidative serum albumin / N. Sakata, A. Moh, S. Takebayashi // Heart Vessels. - 2002. No. 17. - P. 22-29.

3. Human albumin solution for patients with cirrhosis and acute on chronic liver failure: Beyond simple volume expansion / C. Valerio, E. Theocharidou, A. Davenport [et al.] // World J. Hepatol. - 2016. - No. 8. - P. 345-354.

4. Jalan R. Effective albumin concentration and cirrhosis mortality: from concept to reality / R. Jalan, M. Bernardi // J. Hepatol. - 2013. - Vol. 59. - P. 918-920.

5 . Impairment of the antioxidant properties of serum albumin in diabetic patients: protective effects of metformin / P. Faure, N. Wiernsperger, C. Polge [et al.] // Clin. Sci. (Lond.). - 2008. - Vol. 114 (3). - P. 251-256.

6. Hypoalbuminemia accelerates erythrocyte membrane lipid peroxidation in chronic hemodialysis patients / A. Soejima, N. Matsuzawa, N. Miyake [et al.] // Clin. Nephrol. - 1999. - Vol. 51. - P. 92-97.

7. Identification and characterization of oxidized human serum albumin. A slight structural change impairs its ligand-binding and antioxidant functions / A. Kawakami, K. Kubota, N. Yamada [et al.] // Febs J. - 2006. - Vol. 273. P. 3346-3357.

8. Specific antioxidant properties of human serum albumin / M. Taverna, A. L. Marie, J. P. Mira [et al.] // Ann. Intensive Care. - 2013. - No. 3(1). - P. 1-4.

9. Андрейчин С. М. Вплив глутаргіну на зв'язувальну функцію сироваткового альбуміну та інші показники функціонального стану печінки при гострому токсичному гідразиновому гепатиті / С. М. Андрейчин, 
Огляди літератури, оригінальні дослідження, погляд на проблему, випадок з практики, короткі повідомлення

3. С. Скірак // Медична хімія. - 2015. - № 4 (16). C. 66-69.

10. Зубина И. М. Физико-химические свойства альбумина и его функциональная полноценность при хроническом гломерулонефрите : дисс. на соискание ученой степени канд. биол. наук. - СПб, 2001. - 122 с.

11. Oxidative albumin damage in chronic liver failure: relation to albumin binding capacity, liver dysfunction and survival / K. Oettl, R. Birner-Gruenberger, W. Spindelboeck [et al.] // J. Hepatol. - 2013. - Vol. 59. - P. 978-983.

12. Hyperoxidized albumin modulates neutrophils to induce oxidative stress and inflammation in severe alcoholic hepatitis / S. Das, J. S. Maras, M. S. Hussain [et al.] // Hepatology. - 2017. - Vol. 65. - P. 631-646.

13. Degradation of glycated bovine serum albumin in microglial cells / A. Stolzing, R. Widmer, T. Jung [et al.] // Free Radic. Biol. Med. - 2006. - Vol. 40. - P. 1017-1027.

14. Change in serum albumin concentration is inversely and independently associated with risk of incident metabolic syndrome / S. M. Jin, Y. J. Hong, J. H. Jee [et al.] // Metabolism. - 2016. - Vol. 65. - P. 1629-1635.

15. Response of albumin synthesis to oral nutrients in young and elderly subjects / G. Caso, J. Feiner, I. Mileva [et al.] // Am. J. Clin. Nutr. - 2007. - Vol. 85(2).- P. 446-451.

16. Albumin synthesis in humans increases immediately following the administration of endotoxin / $\mathrm{H}$. Barle, A. Januszkiewicz, L. Hallstrom [et al.] // Clin. Sci. (Lond). 2002. - Vol. 103(5). - P. 525-531.

\section{REFERENCES}

1. Levitt, D.G., \& Levitt, M.D. (2016). Human serum albumin homeostasis: a new look at the roles of synthesis, catabolism, renal and gastrointestinal excretion, and the clinical value of serum albumin measurements. International Journal of General Medicine, 9, 229-255.

2. Sakata, N., Moh, A., \& Takebayashi, S. (2002). Contribution of superoxide to reduced antioxidant activity of glycoxidative serum albumin. Heart and Vessels, 17(1), 22-29.

3. Valerio, C., Theocharidou, E., Davenport, A., \& Agarwal, B. (2016). Human albumin solution for patients with cirrhosis and acute on chronic liver failure: Beyond simple volume expansion. World Journal of Hepatology, 8(7), 345-354.

4. Jalan, R., \& Bernardi, M. (2013). Effective albumin concentration and cirrhosis mortality: from concept to reality. Journal of Hepatology, 59(5), 918-920.

5. Faure, P., Wiernsperger, N., Polge, C., Favier, A., \& Halimi, S. (2008). Impairment of the antioxidant properties of serum albumin in patients with diabetes: protective effects of metformin. Clinical Science, 114(3), 251-256.

6. Soejima, A., Matsuzawa, N., Miyake, N., Karube, M., Fukuoka, K., Nakabayashi, K., \& Nagasawa, T. (1999). Hypoalbuminemia accelerates erythrocyte membrane lipid peroxidation in chronic hemodialysis patients. Clinical Nephrology, 51(2), 92-97.

7. Kawakami, A., Kubota, K., Yamada, N., Tagami, U., Takehana, K., Sonaka, I., \& Hirayama, K. (2006). Identification and characterization of oxidized human serum albumin: $A$ slight structural change impairs its ligand-binding and antioxidant functions. The FEBS Journal, 273(14), 3346-3357.
17. Cubilin is essential for albumin reabsorption in the renal proximal tubule / S. Amsellem, J. Gburek, G. Hamard [et al.] // J. Am. Soc. Nephrol. - 2010. - Vol. 21(11). P. 1859-1867.

18. Информативность показателя «эффективная концентрация альбумина» при распространенном перитоните: данные многоцентрового исследования / Ю. А. Грызунов, А. А. Гринберг, В. А. Ступин [и др.] // Анестезиол. реаниматол. - 2003. - № 6. - С. 32-35.

19. Human serum albumin isoforms: genetic and molecular aspects and functional consequences / U. KraghHansen, L. Minchiotti, M. Galliano [et al.] // Biochim. Biophys. Acta. - 2013. - Vol. 1830(12). - P. 5405-5417.

20. Gupta D. Pretreatment serum albumin as a predictor of cancer survival: a systematic review of the epidemiological literature / D. Gupta, C. G. Lis // Nutr. J. - 2010. No. 9. - P. 1-16.

21. The antioxidant properties of serum albumin / M. Roche, P. Rondeau, N. R. Singh [et al.] // FEBS letters. 2008. - Vol. 582. - P.1783-1787.

22. Human serum albumin: from bench to bedside / G. Fanali, A. di Masi, V. Trezza [et al.] // Mol. Aspects Med. 2012. - № 33(3). - P. 209-290.

23. The oxido-redox potential of albumin methodological approach and relevance to human diseases / G. Candiano, A. Petretto, M. Bruschi [et al.] // J. Proteomics. - 2009. - Vol. 73. - P. 188-195.

8. Taverna, M., Marie, A.L., Mira, J.P., \& Guidet, B. (2013). Specific antioxidant properties of human serum albumin. Annals of Intensive Care, 3(1), 1-7.

9. Andreychyn, S.M., \& Skirak, Z.S. (2014). Vplyv hlutarhinu na zvyazuvalnu funkciyu syrovatkovogo albuminu ta inshi pokaznyky funkcionalnogo stanu pechinky pry gostromu toksychnomu gidrazynovomu gepatyti [Effect of glutargine on serum albumin binding function and other indicators of liver function in acute toxic hydrazine hepatitis]. Medychna khimiya - Medical Chemistry, 16, 4, 66-69 [in Ukrainian].

10. Zubyna, Y.M. (2001). Fiziko-himicheskie svoystva albumina i ego funktsionalnaya polnotsennost pri hronicheskom glomerulonefrite [The physical and chemical properties of albumin and its functional fullness in chronic glomerulonephritis] diss. na soiskaniye uchionoi stepeni kand.biol. nauk - dissertation for the degree of Cand. biol. sciences. SPb [in Russian].

11. Oettl, K., Birner-Gruenberger, R., Spindelboeck, W., Stueger, H.P., Dorn, L., Stadlbauer, V., \& Stauber, R.E. (2013). Oxidative albumin damage in chronic liver failure: relation to albumin binding capacity, liver dysfunction and survival. Journal of Hepatology, 59(5), 978-983.

12. Das, S., Maras, J.S., Hussain, M.S., Sharma, S., David, P., Sukriti, S., \& Sarin, S.K. (2017). Hyperoxidized albumin modulates neutrophils to induce oxidative stress and inflammation in severe alcoholic hepatitis. Hepatology, 65(2), 631-646.

13. Stolzing, A., Widmer, R., Jung, T., Voss, P., \& Grune, T. (2006). Degradation of glycated bovine serum albumin in mi- 
Огляди літератури, оригінальні дослідження, погляд на проблему, випадок з практики, короткі повідомлення croglial cells. Free Radical Biology and Medicine, 4O(6), 10171027.

14. Jin, S.M., Hong, Y.J., Jee, J.H., Bae, J.C., Hur, K Y., Lee, M.K., \& Kim, J.H. (2016). Change in serum albumin concentration is inversely and independently associated with risk of incident metabolic syndrome. Metabolism, 65(11), 1629-1635.

15. Caso, G., Feiner, J., Mileva, I., Bryan, L. J., Kelly, P., Autio, K., \& McNurlan, M.A. (2007). Response of albumin synthesis to oral nutrients in young and elderly subjects. The American Journal of Clinical Nutrition, 85(2), 446-451.

16. Barle, H., Januszkiewicz, A., Hållström, L., Essén, P., McNurlan, M. A., Garlick, P.J., \& Wernerman, J. (2002). Albumin synthesis in humans increases immediately following the administration of endotoxin. Clinical Science, 103(5), 525-531.

17. Amsellem, S., Gburek, J., Hamard, G., Nielsen, R., Willnow, T.E., Devuyst, O., \& Kozyraki, R. (2010). Cubilin is essential for albumin reabsorption in the renal proximal tubule. Journal of the American Society of Nephrology, 21(11), 1859-1867.

18. Gryizunov, Yu.A., Grinberg, A.A., Stupin, V.A., Rodoman, G.V., Musselius, S.G., Fedorovskiy, H.M., \& Naumov, E.K. (2003). Informativnost pokazatelya «effektivnaya kontsentratsiya albumina» pri rasprostranennom

peritonite: dannyie mnogotsentrovogo issledovaniya [Informative value of the indicator "effective concentration of albumin" in generalized peritonitis: data from a multicenter study]. - Anesteziol. i Reanimatol. - Anastesiol. Reanimatol., (6), 32-35 [in Russian].

19. Kragh-Hansen, U., Minchiotti, L., Galliano, M., \& Peters Jr, T. (2013). Human serum albumin isoforms: genetic and molecular aspects and functional consequences. Biochimica et Biophysica Acta (BBA)-General Subjects, 1830(12), 5405-5417.

20. Gupta, D., \& Lis, C.G. (2010). Pretreatment serum albumin as a predictor of cancer survival: a systematic review of the epidemiological literature. Nutrition Journal, 9(1), 1-16.

21. Roche, M., Rondeau, P., Singh, N.R., Tarnus, E., \& Bourdon, E. (2008). The antioxidant properties of serum albumin. FEBS letters, 582(13), 1783-1787.

22. Fanali, G., Di Masi, A., Trezza, V., Marino, M., Fasano, M., \& Ascenzi, P. (2012). Human serum albumin: from bench to bedside. Molecular Aspects of Medicine, 33(3), 209-290.

23. Candiano, G., Petretto, A., Bruschi, M., Santucci, L., Dimuccio, V., Prunotto, M., \& Ghiggeri, G.M. (2009). The oxido-redox potential of albumin: Methodological approach and relevance to human diseases. Journal of Proteomics, 73(2), 188-195.

\section{SYNTHESIS AND SERUM ALBUMIN FUNCTION DISORDERS IN DIFFERENT PATHOLOGICAL CONDITIONS OF THE BODY}

\section{○Yu. R. Dzordzo, S. M. Andreychyn, U. O. Mudra \\ I. Horbachevsky Ternopil National Medical University}

SUMMARY. The review highlights the data of the modern literature on pathological changes in the metabolism and function of serum albumin in various diseases and pathological conditions.

The aim - to conduct the analysis of publications on serum albumin dysfunction and their impact on the body, as well as to show the prospects for further research in this area.

Material and Methods. Biblio-systematic and analytical methods were used in the study. A review and analysis of modern literature was carried out in the Medline and PubMed database.

Results. Briefly covered modern understanding of the synthesis and function of human serum albumin, causes a decrease in its concentration in blood plasma, quantitative and qualitative changes in various pathological conditions. Report on the latest literature data on the transport and antioxidant properties of albumin, its structural changes.

Conclusions. The prevalence of albumin in the human body and the diversity of its functions determines the importance of the influence of various pathological processes on its metabolism. The main factors that cause changes in albumin metabolism are diseases that lead to disruption of its formation, increased loss, and redistribution between tissues, as well as structural changes that affect the function of this protein.

KEY WORDS: albumin; albumin synthesis and function disorders; hypoalbuminemia; hyperalbuminemia. 